NBER WORKING PAPER SERIES

\title{
CROSS-SECTORAL EXTERNALITIES RELATED TO NATURAL RESOURCES AND ECOSYSTEM SERVICES
}

\author{
Manuel Bellanger \\ Robert Fonner \\ Daniel S. Holland \\ Gary D. Libecap \\ Douglas W. Lipton \\ Pierre Scemama \\ Cameron Speir \\ Olivier Thébaud \\ Working Paper 28480 \\ http://www.nber.org/papers/w28480
}

\author{
NATIONAL BUREAU OF ECONOMIC RESEARCH \\ 1050 Massachusetts Avenue \\ Cambridge, MA 02138 \\ February 2021
}

The views expressed herein are those of the authors and do not necessarily reflect the views of the National Bureau of Economic Research.

NBER working papers are circulated for discussion and comment purposes. They have not been peer-reviewed or been subject to the review by the NBER Board of Directors that accompanies official NBER publications.

(C) 2021 by Manuel Bellanger, Robert Fonner, Daniel S. Holland, Gary D. Libecap, Douglas W. Lipton, Pierre Scemama, Cameron Speir, and Olivier Thébaud. All rights reserved. Short sections of text, not to exceed two paragraphs, may be quoted without explicit permission provided that full credit, including $\left({ }^{\circ}\right.$ notice, is given to the source. 
Cross-sectoral Externalities Related to Natural Resources and Ecosystem Services

Manuel Bellanger, Robert Fonner, Daniel S. Holland, Gary D. Libecap, Douglas W. Lipton,

Pierre Scemama, Cameron Speir, and Olivier Thébaud

NBER Working Paper No. 28480

February 2021

JEL No. D23,H23,H73,P48,Q20,Q22

\section{ABSTRACT}

Standard approaches to environmental and natural resource use externalities generally focus on single-sector resources and user groups. Remedies include Pigouvian-style government constraints, small group controls following Elinor Ostrom, or less frequently, bargaining across users as outlined by Ronald Coase. However, many difficult natural resource management problems involve competing uses of the same resource or multiple interdependent resources, across multiple, heterogeneous sectors. Cross-sectoral externalities are generated and impede attainment of conservation objectives. The multiplicity of resources and stakeholders, who may have different property rights, hold different use or non-use values, have different traditions, or fall under different regulatory regimes, increases the likelihood of multi-jurisdictional conflicts. We provide an institutional analysis following Oliver Williamson's four-levels of institutions (social embeddedness, institutional environment, governance, resource allocation) to illustrate the sources of potential conflict, the costs of addressing them, and the potentials for exchange. In comparing the costs of alternative approaches, we include transaction costs associated with property rights; the costs of lobbying, implementing, and enforcing government regulation; and the costs of scaling up from small-group controls when resource problems involve multiple sectors and heterogeneous populations. In our illustrative case examples, instruments that are not formal property rights are exchanged at lower transaction costs. We close by discussing how Coasean, Pareto-improving voluntary exchange agreements may be lower cost, more effective, and more durable solutions than alternative management regimes to mitigate cross-sectoral externalities.

Manuel Bellanger

Unité d'Economie Maritime UMR

6308 AMURE

Ifremer, Univ Brest, CNRS, IUEM

Plouzane

France

manuel.bellanger@ifremer.fr

Robert Fonner

Northwest Fisheries Science Center

NOAA Fisheries

Seattle, WA 98112

robby.fonner@noaa.gov
Daniel S. Holland

Northwest Fisheries Science Center

NOAA Fisheries

Seattle, WA 98112

dan.holland@noaa.gov

Gary D. Libecap

Distinguished Professor,

Bren School of Environmental Science

and Management

Distinguished Professor of Economics

University of California, Santa Barbara

(Emeritus)

400 Daly Avenue

Missoula, Montana 59801

and NBER

glibecap@bren.ucsb.edu 
Douglas W. Lipton

NOAA Fisheries

Silver Spring, MD 20910

dlipton@umd.edu

Pierre Scemama

Unité d'Economie Maritime

UMR 6308 AMURE

Ifremer, Univ Brest, CNRS, IUEM

Plouzane

France

pierre.scemama@ifremer.fr

Cameron Speir

Southwest Fisheries Science Center

NOAA Fisheries

Fisheries Ecology Division

Santa Cruz, CA 95060

cameron.speir@noaa.gov

Olivier Thébaud

Unité d'Economie Maritime

UMR 6308 AMURE

Ifremer, Univ Brest, CNRS, IUEM

Plouzane

France

olivier.thebaud@ifremer.fr 


\section{Introduction}

Common-pool resources, including open-access fisheries, aquifers, irrigation systems, pastures, forests, earth's oceans and atmosphere, tend to be rapidly and wastefully exploited by individual users whose incentives to maximize short-term profits oppose collective interests (Gordon, 1954; Hardin, 1968). The economic analysis of institutions has made important contributions to the study of common-pool externalities (Scott, 1955; Demsetz, 1967; Dahlman, 1979; Libecap, 1989, 1994; Bromley, 1992; Ostrom, 1990, 2009; Williamson, 1996, 2000). The field of institutional economics has examined the particular role of property rights regimes and their implication for economic behavior in relation to societal institutions. It has also been at the forefront of the search for understanding the functioning of governance systems and the emergence of new modes of organizations. In the case of the exploitation of a local common-pool resource, theory and empirical evidence have often focused on solutions to address externalities and resulting overexploitation of resources within sectors. However, with the increasing pressure of human activities on biodiversity and ecosystems, more complex situations - such as multiple sectors exploiting distinct but interconnected resources whose ecological production and human exploitation span large geographical scales and multiple jurisdictions - have emerged (Crowder et al., 2006; Sanchirico et al., 2010; Grip, 2017). For instance, marine and coastal activities are often closely interrelated, and resources spanning marine and coastal environments are also likely to span multiple jurisdictional boundaries and ecological structures where stakeholders have different values and objectives for resource management (Bellanger et al., 2020). These settings make it critical to take into account cross-sector interactions and heterogeneities to foster coordination in addressing resource-use externalities (Rice, 2011).

We focus on complex natural resource management problems where competing uses of the same resource, or multiple interdependent resources, by numerous sectors generate crosssectoral externalities that impede attainment of conservation objectives. These "wicked" problems are difficult to define and cannot be solved by using typical scientific models (Batie, 2008; Groeneveld, 2020). Cross-sectoral conflicts exacerbate the difficulties that are traditionally found in reducing common-pool externalities, including divergent preferences across stakeholder groups, distributional issues, information problems, and compliance (Crowder et al., 2006; McCann, 2013). Further difficulties also arise from having pre-established institutional systems that have developed independently from one another, resulting in governance institutions with overlapping and conflicting mandates within and across resources, economic sectors, biomes, and jurisdictional boundaries. The different groups often hold conflicting opinions on the type of action that needs to be implemented and the timing of intervention. These concerns increase the transaction costs of reaching agreement on appropriate remedies (Libecap, 2014). Cross-sectoral conflicts can also involve values that cannot easily be traded-off, such as non-use values for endangered species in the face of potentially irreversible losses (Bishop, 1978).

In its most basic definition, "cross-sectoral" is used when something relates to more than one group of stakeholders. Bryson et al. (2006) describe cross-sectoral collaboration as partnerships involving government, business, nonprofits and philanthropies, communities, and/or the general public. The distinction between public/government, commercial and nonprofit sectors is relevant but insufficient to characterize cross-sectoral issues as some can involve multiple commercial sectors for example. For our purpose, more useful definitions of the differences between sectors can be based on differences in how the resource is valued by a group (e.g., for use or non-use), means of production, benefits from ecosystem services, distinct jurisdictions, etc. A common theme across definitions is that 
"cross-sectoral" entails a notion of heterogeneity of uses and users, and the several possible definitions can be viewed as a gradient in how heterogeneous user groups need to be in order to be considered as different sectors (Neely et al., 2017). Beyond stakeholder heterogeneity, the characteristics of the biophysical environment and the multi-jurisdiction nature of externality problems generate specific challenges (Folke et al., 2007; Ostrom, 2009).

\subsection{Case examples of cross-sectoral conflicts}

Examples of governance conflicts at the interface of multiple sectors and jurisdictions include management regimes for diadromous species of conservation concern (e.g., salmon, eel, river herring, etc.), where fish that migrate between river and sea are subject to intense human harvest, disruption of watersheds by dams and land uses, reduced stream flow caused by agricultural water diversions, predation, and other threats. Each of these water uses involves different parties, whose practices are governed by different regulatory agencies and regimes. These regulatory efforts are aimed primarily at reducing externalities within a sector and are not designed specifically to address broader problems across the resource. The result in some sectors is important loss in use and non-use values.

For instance, Lackey (2017) describes a durable 'salmon crisis' on the US West coast where the different ecosystem services that are involved in the conflicts are linked. This case reveals the heterogeneity attributes that are characteristic of cross-sectoral externalities: multiple sectors competing for uses of interdependent resources spanning multiple biomes and distinct jurisdictions, conflicts between use and non-use values, and uncertainty regarding the extent of external effects across sectors and resources. River flows are used as a direct input to hydropower, agriculture, and salmon habitat. Salmon is also an input to commercial, recreational, and indigenous fishing and serve as key prey species for marine mammals including endangered Southern Resident Killer Whales, which, like salmon, hold significant cultural value and also support a whale-watching industry. While the use of water as input to hydropower and agriculture is fairly predictable and visible, its effect on salmon production is more variable, less certain, and less visible to most user groups. Hydropower flow rules and management of water diversions for agriculture may ignore their indirect impacts on marine mammals due to reduced prey abundances. Likewise, marine mammals' managers may not be able to address issues related to hydropower and agriculture. At the cross-road of these conflicts and others involving logging, hatchery policies, development and water pollution, salmon recovery institutions are struggling to reverse the long-term decline of wild Pacific salmon in the USA (Northwest Fisheries Science Center, 2015).

The collapse of Pacific leatherback sea turtle populations is another illustration of crossbiome conflicts that undermine biodiversity conservation (Spotila et al., 2000). Factors contributing to ocean mortality of leatherback turtles include incidental fisheries bycatch and direct harvest. On nesting beaches, egg and hatchling mortality is due to coastal development, predation, egg harvest, and other beach-related sources of mortality (Tapilatu et al., 2013). Illegal egg poaching on nesting beaches undermines conservation efforts and exposes very contrasting preferences between conservationists and some local communities where turtle egg consumption is associated with traditions and beliefs (Tomillo et al., 2008). As all stages of the life cycle are essential for population persistence, understanding the tradeoffs involved in protecting nesting beaches and breeding habitats, and regulating bycatch and subsistence takes at-sea, is imperative for conservation and population recovery (Gjertsen et al., 2014). 
Wolf management is a third telling example of cross-sectoral conflicts. Human perceptions of wolves vary from iconic biodiversity symbol to a source of human fears of the wild, while reaction to the losses from attacks on livestock can lead to illegal killing of protected wolves (Salvatori and Linnell, 2005). Wolf habitats typically range over hundreds of kilometers and span across jurisdictional boundaries (Gehring and Potter, 2005). Thiel et al. (2012) describe a case where wolf protection reduces the value of the property rights of livestock owners and wild game provisioning services, while providing positive cultural services and non-use values. Therefore, the distribution of costs and benefits of wolf protection varies considerably across stakeholder groups. Moreover, wolves are highly mobile and the time and location of livestock attacks by wolves, which depend on wild game availability, are very difficult to predict. These characteristics increase the transaction costs of addressing stakeholder conflicts. Thiel et al. (2012) report that the state may play a key role in organizing the social-ecological transaction between sectors, depending on the incentives of politicians and agency officials.

\subsection{Characterizing cross-sectoral conflicts and perspectives for their resolution: an institutional economics analysis}

Clarifying management tradeoffs across heterogeneous sectors and jurisdictions embracing the complexity of positive and negative effects associated with alternative management options, as required to address cross-sectoral externalities - is a challenge under traditional single-sector regulatory approaches. Addressing broad externalities requires consensus, aligned incentives, and a proportionate distribution of benefits and costs across diverse sectors (Ostrom, 1990; Cox et al., 2010). More narrow government interventions (Pigou, 1932) or small-group collective action (Ostrom 1990) typically are not designed for cross-sectoral coordination and joint action among heterogeneous parties for several reasons.

First, the multiplicity of interacting resources being valued by different stakeholders increases the likelihood of jurisdictional conflicts across regulatory authorities and the difficulty of managing the system. No single agency generally has authority to address these conflicts in a manner that generates support among varying users. Second, differences in use and non-use values between sectors may have important implications for addressing externalities. For example, organized citizen groups and non-profit organizations that emphasize significant non-use values may pressure policy-makers to implement measures to protect and recover at-risk biodiversity. On the other hand, use sectors frequently invoke traditions or socio-economic considerations to lobby against policy measures that restrain their activities. Fulfilling the demand for biodiversity conservation typically modifies historical practices or the formal or informal property rights of user groups, without compensation. The predictable result is opposition, delay, or evasion, undermining resource objectives. Standard regulatory governance structures are not designed to promote exchange among these differential parties. Indeed, some parties may not want to compromise if they believe their political influence may advance certain of their strongly-held values. The costs of competitive lobbying and enforcement also rise as other parties find their positions or livelihoods compromised.

System complexity, which is characterized in terms of heterogeneity in stakeholders, biophysical systems, and institutions, raises the cost of cross-sector coordination. The literature on determinants of transaction costs associated with environmental policymaking has analyzed heterogeneity-related attributes such as multiplicity of stakeholders groups (Libecap, 2005; McCann, 2013), power imbalance (Krutilla and Krause, 2011), mobility of the resource (Libecap, 2014), and institutional misalignments (Krutilla and 
Krause, 2011; Marshall, 2013; McCann, 2013; Libecap, 2014). Heterogeneity increases the cost of organizing relations between groups because of practical reasons such as their number and location (Coggan et al., 2010), or because of the lack of trust (Mettepenningen and van Huylenbroeck, 2009) and social connectedness (Morrison et al., 2008). Notably, two of the most influential strands of literature on the economic analysis of environmental governance, Elinor Ostrom's social-ecological systems framework and Oliver Williamson's transaction cost approach, both predict that these cross-sectoral conflicts will not have straightforward bargaining-based solutions in the absence of government intervention. Even government intervention, however, requires lobbying of politicians and agency officials, and when the parties hold different resource objectives, lobby efforts compete, molding and potentially delaying any response. Accordingly, heterogeneity and different cultural norms between user groups, geographic dispersion, uncertainties regarding system dynamics, asymmetry of information, are factors that are known to impede self-organized governance systems (Ostrom, 1990, 2009) and increase the transaction costs of reaching agreement on solutions to address externalities (Libecap, 1994; Williamson, 1996), allowing conflicts to expand and persist.

Where such heterogeneities exist, they are outside of the small, homogenous groups and corresponding shared values and trust among parties found by Ostrom (1990) to promote collective action. Accordingly, it may not be feasible to scale up or coordinate across different groups and jurisdictions at low cost to achieve joint resource objectives. Moreover, with competing interests in such settings, lobbying for Pigouvian-style taxes (Pigou, 1932) or restrictions on access and use, or for eliciting government support of cross-jurisdictional collective action, typically encounters conflicting stakeholder objectives. Competing interests and the uncertain political and bureaucratic response to them raise the costs of securing jointly-agreed government support. When these costs are weighed with the transaction costs identified by Coase (1960) and Williamson (1996, 2000), Coasean alternatives based on voluntary bargaining among stakeholder groups may be more cost-effective and durable than government constraints or deliberative approaches (Ovando et al., 2021).

Consider the following two examples. Since at least 2001, there have been concerns about overfishing of Bigeye tuna in the Western Central Pacific Ocean (Ovando et al, 2021). Overfishing occurs from the bycatch of juvenile Bigeye that school with Skipjack tuna under fish aggregating devices (FADs). 19 countries have long line or purse seine vessels harvesting Bigeye and 17 countries have purse seine vessels in the much larger Skipjack fishery. Further, international environmental NGOs value ecosystem services provided by Bigeye stocks. These multiple interests have been in conflict, blocking agreement on conservation measures. The primary remedy is reduction in FAD use by Skipjack interests, but doing so imposes productivity losses on those vessels without compensation. To break the impasse, Ovando et al. (2021) propose a Coasean bargain whereby the parties seeking FAD removals would purchase Vessel Day Scheme (VDS) licenses held by Skipjack vessel owners and reduce FAD use. VDS licenses to fish are sold to fishing vessel owners by Parties to the Nauru Agreement, countries whose members control access valuable fishing waters. Under the proposal, parties desiring reduced FADs and Bigeye conservation would purchase VDS licenses from Skipjack vessel owners and restrict FAD use in fishing. The aggregate bargain across participating agents not only determines overall voluntary Bigeye conservation, but compensates the vessel owners who give up FADs to achieve it. Doing so elicits their support of conservation. This Coasean bargain occurs at lower transaction costs because formal property rights to fish Bigeye are not defined, and rather the exchange uses existing VDS licenses that serve as a mechanism for exchange. 
Similarly, consider the role of Fiordland Marine Guardians - a statutory advisory body appointed by the Minister for the Environment - in coordinating non-traditional instrument exchanges for conservation among the various parties that depend upon the waters off the southwest portion of the South Island of New Zealand (Guardians of Fiordland's Fisheries and Marine Environment Inc., 2003, 2020). The stakeholders and values are heterogeneous and competitive, ranging from commercial and recreational fishers to indigenous Maori customary fishing and non-use values, to tourism, to NGO members who value biodiversity and other forms of non-use. Multiple government, cross-sectoral regulatory agencies are involved with overlapping, but not aligned mandates. To reduce fishing pressure on vulnerable species and prized ecosystems, to limit tourism and associated pollution, and to constrain the introduction of invasive species, the Fiordland Marine Guardians play a key role in a Coasean exchange. The Guardians have an officiallyrecognized role as a neutral party for negotiating conservation strategies, developing codes of practice, and monitoring compliance among the actors in each sector. They oversee the exchange of "gifts and gains" among the parties to achieve conservation goals (Guardians of Fiordland's Fisheries and Marine Environment Inc., 2003, p.14-16, 79-81). These include temporary closures, reductions in harvests, and limited access to sensitive areas. These arrangements are voluntarily agreed to by the negotiating parties. The background institutions and incentives for exchange include formal fishing rights, individual transferable quotas (ITQs) held by commercial fishers, who seek to avoid local depletion and external imposition of fishing controls, the desire of tourism groups to avoid additional limits on access to high-profile areas, NGOs that seek to protect special ecological areas, Maori groups that want recognition of their historical areas and customary practices, and recreation fishers that desire access. In negotiations, each group trades portions of its preferred independent, unconstrained objective to obtain broader collaboration by the overall group and the government agencies under which they operate (Guardians of Fiordland's Fisheries and Marine Environment Inc., 2003, p.14, 17-18, 79-81).

The article is structured as follows. The next section provides background on the standard theoretical framework for the institutional analysis of traditional common-pool allocation problems. We then extend this framework to characterize cross-sectoral and crossjurisdictional externalities. To this end, impediments to more integrated institutional systems are examined in light of Williamson's (2000) four-levels of institutions. The article then discusses reliance upon voluntary Coasean bargaining as an alternative to traditional regulation and the case examples above are used to illustrate how the consideration of institutional factors relating to Williamson's framework can help identify opportunities for feasible arrangements to mitigate cross-sectoral conflicts.

\section{Institutional analysis of common-pool allocation problems}

\subsection{Common-pool externalities}

Common-pool externality problems have led to the depletion of many valuable commonpool resources worldwide (MEA, 2005). This wasteful process results from the disconnect between the private costs incurred by individual users acting independently and the full social costs of their activities (Dahlman, 1979). When resource users do not bear the full social cost of their activities, they exploit the resource too intensively with short-term incentives predominating over long-term consequences.

To reduce the losses of the commons, constraints on individual behavior can be imposed so as to better take into consideration the social benefits and costs of common-pool resource 
exploitation. For instance, these limits can be designed to promote higher-valued uses of the resource or to spread the resource across generations of users. In general, when a common-pool resource is accessed locally by few and homogenous groups of users, cultural norms and collective-choice arrangements can reduce common-pool losses (Ostrom, 1990). By contrast, when the set of competitors is larger and more heterogeneous or when the resource is highly mobile across a vast geographic scale, such collectivechoice arrangements may not be effective in reducing open-access losses and more formal state intervention may be required to address common-pool externalities (Cox et al., 2010). These can range from the taxes described by Pigou (1932); regulatory constraints on access and use to better equate social benefits and costs; or the assignment of a property right of some type that more fully aligns private and social costs and benefits and that can be traded (Coase, 1960).

\subsection{Property rights regimes}

Property rights are a form of regulation of access to, and use of, a resource. The emergence of property rights has been shown to derive from the existence of negative externalities (Demsetz, 1967; Scott, 1955). The philosophy behind rights-based approaches to mitigating common pool losses is to internalize the costs that a resource user's actions impose on others and to capture the gains from increases in resource values. The characteristics of property rights are traditionally described with four main attributes that allow evaluation of their 'completeness': the right to use the resource, the right to derive profit from the resource, the right to transfer ownership, and the right to enforce property rights (Eggertsson, 1990). The costs of defining, transferring, monitoring, and enforcing property rights are referred to as transaction costs (Eggertsson, 1990; McCann et al., 2005; Krutilla and Krause, 2011; Marshall, 2013; Libecap, 2014).

Property rights determine the nature of the possible uses of a resource and its associated flow of benefits accruing to the owner; they also determine the costs that the owner may impose on others through his use of the resource. By determining who is entitled to the costs and benefits of decisions to use a resource, property rights ultimately structure the incentives that guide agents in their individual decisions (Libecap, 1989). A property rights regime still requires that a higher authority with coercive power and legitimacy, usually the State, is able to impose obligations on third parties who may covet or act on that resource (Bromley, 1992). According to Arrow (1974), a higher authority may be necessary to address equity issues, as well as to overcome market failures. Furthermore, property rights are complemented by institutional arrangements providing for coordination and enforcement mechanisms (Williamson, 1996).

\subsection{Institutional change to internalize common-pool externalities}

Institutional change results from efforts undertaken by individuals and stakeholder groups to modify collective rules governing their activity in order to avoid the losses due to common-pool externalities (Libecap, 1989). Williamson (2000) developed a framework for analyzing institutions and institutional change that distinguishes four levels corresponding to different types of institutions: social embeddedness, institutional environment, governance, and resource allocation (see Figure 1, which is derived from Williamson's Figure $1(2000$, p. 597)). This framework defines the options and structures for crosssector coordination to address environmental and natural resource externalities. It links the different levels of institutions with different frequencies of change and different purposes of institutional design at the different levels. Each level of institutions may play a critical role in devising incentive-compatible responses. 
In Figure 1, institutions in the lower levels are nested within and directly affected by higher levels of institutions, while feedback processes link lower levels to higher levels. According to this framework, the property rights regime and institutional environment which are embedded within informal institutions, such as social norms and traditions, do not change immediately in reaction to changes in governance system or resource allocation. The timescale of institutional change may also be substantially different from the timescales of natural processes and perceptions of change in ecosystems. Informal institutions and the legal system play an important role in influencing the modes of coordination, structuring interactions among stakeholders, and shaping individual incentives and behavior. Therefore, the question of institutional design needs to account for this interconnectedness between all levels of institutions - both formal and informal.

The transaction costs associated with defining, monitoring, and enforcing formal property rights are generally not low enough to ensure the complete definition of a property right as well as smooth redistribution through trade (Coase, 1960). For these reasons, in the cases examined above, alternative mechanisms - VDS licenses in the Bigeye tuna case as well as "gifts and gains" in the New Zealand Fiords - were the basis of exchange. These arrangements follow from Williamson's schematic that extends the institutional environment to include the governance level. He described governance as "an effort to craft order, thereby to mitigate conflict and realize mutual gains" (Williamson, 2000). Determining which governance structures will minimize transaction costs is therefore an underappreciated dimension in addressing complex common-pool problems. To this end, it is useful to examine the determinants of transaction costs and their effects on the likelihood of collective action to address externalities (Krutilla and Krause, 2011; Libecap, 2014; Marshall, 2013; McCann, 2013).

Figure 1: Williamson's framework for analyzing institutions and institutional change. Adaptation of Figure 1. Economics of Institutions in Williamson (2000, p. 597)

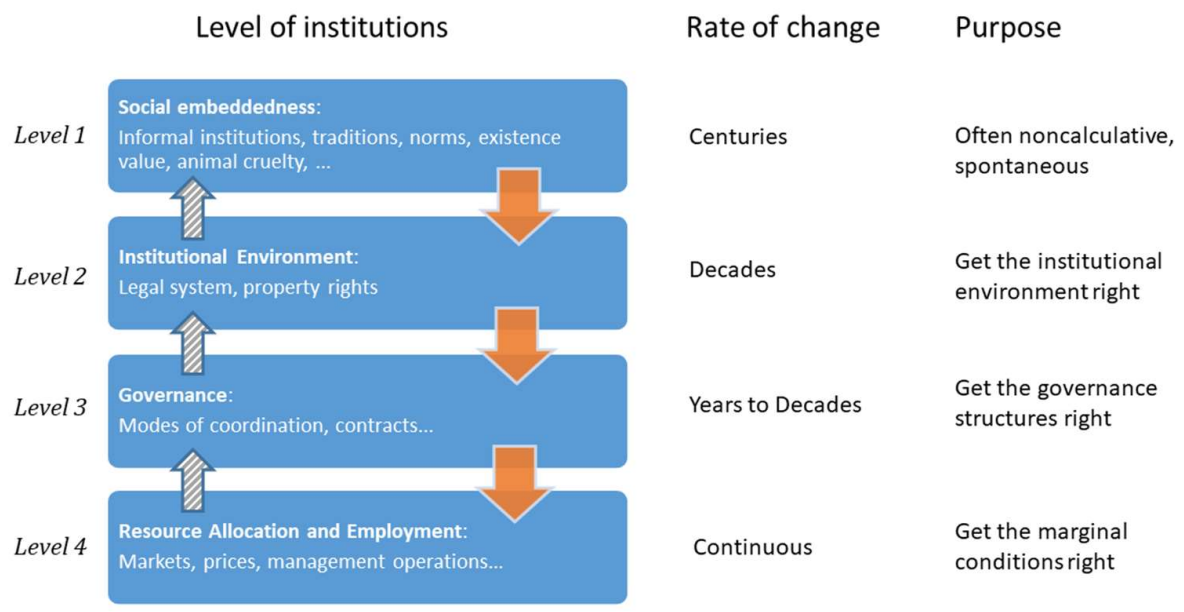

\subsection{Externality problems in multiple sector settings}

The initial development of institutions around common-pool externality problems tends to 
be based on single-sector approaches, even when multiple sectors exploit the same resource or several interdependent resources (Crowder et al., 2006; Grip, 2017). This is particularly likely when sectors are under different government agency jurisdictions. Institutions typically develop in response to the uses and externalities that are immediately apparent, ignoring those that are less apparent. The question of coordinating management operations across sectors only arises when cross-sectoral externalities become sufficiently large relative to the costs of addressing them (Demsetz, 1967). The reasons for crosssectoral externalities to become apparent include: continued depletion of a resource; technical change within one sector that increases exploitation; new ecological thresholds and regime shifts; institutional change, perhaps from external sources; new scientific understanding of the resource and problem; and emergence of broader socio-economic contexts or social norms regarding the resource (Folke et al., 2004; Young, 2010; Hiedanpää and Bromley, 2016).

Before this critical point, multiple sector-based institutional regimes might have emerged and co-existed without much interaction or cross-sectoral coordination (Crowder et al., 2006). Taking into consideration these additional cross-sectoral externalities challenges established sector-based institutional systems, including the definition of individual rights, traditions, and formal governance systems. Even if the potential aggregate gains of crosssectoral coordination are large, the emergence of institutions with a cross-sectoral focus can be hampered by excessive transaction costs associated with additional institutional change to meet the new conditions (Coase, 1960).

\section{Impediments to integrating institutional systems across sectors}

The factors raising the transaction costs of addressing cross-sectoral externalities include: scientific uncertainty regarding mitigation benefits and costs; varying preferences and perceptions across heterogeneous populations; asymmetric information; and anticipation of non-compliance with agreement rules (Libecap, 2014). Further difficulties also arise from having pre-established institutional systems that have developed independently from one another with different supportive constituents. The different groups may hold conflicting opinions on the nature of the resource problem and the type of action that needs to be implemented and the timing of intervention. These concerns increase the transaction costs of reaching agreement on appropriate remedies.

In the following subsections, we review impediments to integrated, cross-sectoral institutional systems in light of the four levels identified in Williamson's analytical framework. These factors play critical roles in devising solutions to cross-sectoral externality problems.

\subsection{Level 1 - Social embeddedness}

Social embeddedness encompasses informal institutions such as traditions, experience, ethics, and social norms, which are assumed to change only slowly. Each user group has its own value system that affects the way alternative policies are perceived and weighed. Certain types of intervention that are considered unethical among a set of stakeholders may not be included in the set of strategies contemplated by the stakeholders and policy makers. For instance, the current policy debate on the protection of some marine mammals that prey on endangered species is disconnected from ecological scientific knowledge: culling predators to rebuild stocks of endangered prey species is considered immoral by some (Lute and Attari, 2017). Social norms also influence the perceived legitimacy of interventions and therefore compliance (Hatcher et al., 2000). These value systems can be 
viewed as informal constraints, social transmission of collective frameworks that provide a common basis to individuals for interpreting signals from their environment. Social and scientific representations have a core role in the development of these collective views that support conservation policy intervention. The more heterogeneous the set of stakeholders, the more their value systems are likely to differ in ways that raise the costs of consensus on cross-sectoral collaboration.

One of the recent evolutions influencing the world views of scientists and managers is the paradigm shift in the ecology community regarding the use of historical baselines for managing human-altered ecosystems. It is increasingly acknowledged that humans have always transformed ecosystems they interact with and that it might be impossible to return ecosystems to a pristine state and thus it may be irrelevant to manage human-altered ecosystems using historical baselines (Hobbs et al., 2013). In this view, humans have to be proactive and think about their values and the compromises they are willing to make or costs they are willing to bear, e.g. to recover endangered species. This is particularly relevant if there is a new epoch, the Anthropocene, characterized by the significant impacts of humans on Earth's geology and ecosystems (Dirzo et al., 2014; IPBES, 2019). To the extent that this ecology community reflects the broader public or influences their perception of environmental issues, then we could expect related norms and values to change more quickly in Anthropocene than assumed in the Williamson framework. If so, the time scale on the higher levels of the framework may be speeded up, inducing changes in the lower levels and creating opportunities for institutional change.

\subsection{Level 2 - Institutional environment}

Laws reflect different ways in which various political constituencies value ecosystems. For instance, fisheries laws (e.g., Magnuson-Stevens Act in the US, Common Fisheries Policy in the EU) set objectives of reaching optimal yields: they are use-oriented. In contrast, biodiversity conservation laws (e.g., Endangered Species Act and Marine Mammal Protection Act in the US, Habitat Directive and Bird Directive in the EU) that aim to prevent species extinctions reflect non-use values (e.g., existence value). The development of sector-based institutional systems in parallel can lead to overlapping and conflicting legal mandates (e.g., species conservation vs. harvest promotion) without overarching regulations to address cross-jurisdictional conflicts.

Moreover, property rights require exclusion, and property rights that do not prevent negative impacts due to the exploitation of the same or interconnected resource by another sector are incomplete. Because of transaction costs in defining property rights, they are always likely to be incomplete and the question arises as to the magnitude of spillover costs. Policy interventions, such as modification of existing property rights regimes, may be opposed if they raise equity concerns or if existing owners are not compensated for their losses. The likelihood that policymakers take broad and resolute action is higher when the public as a whole is concerned by an issue, rather than just the community of environmental experts (Burns, 2008). The inherent complexity of cross-sectoral issues, however, makes it more difficult for citizens to be well informed about the consequences of the externality problem. Voting decisions by elected representatives on environmental policies are largely influenced by the ideology and the economic interests of representatives' constituencies (Yandle, 1989). Beyond ideology divergences, regional considerations and population demographics may also provide insights on voting decisions regarding environmental issues (Burns, 2008). Therefore, the opportunities provided by decentralized governments may be critical for durable political support to more grassroots, bottom-up approaches (Grant and Tilley, 2019). 
Political incentives may hinder legislative change aimed at incorporating cross-sectoral management considerations into the institutional environment. The incentive of politicians to respond to particularistic concerns as compared to providing broad, general values depends on interest group lobbying and time frames (Peltzman, 1976; Volden and Wiseman, 2007). Interest group lobbying does not just influence the final vote on environmental policies. Consultations during the development of a bill and early rounds of voting on amendments may be important for the choice of policy instruments but are generally less visible to the public. The early stages of policy development are likely to be influenced by concentrated interests with important lobbying capacity, rather than broad societal interests. Theories of the political economy of environmental regulation hold that political solutions emerge from the confrontation among key interest groups competing for influence and that these solutions are generally sub-optimal (Hahn, 1990; Aidt, 1998). Industry-related interest groups historically have been thought to have the advantage that they face lower organizational and lobbying costs than groups which benefit from environmental policy. If so, they may be able to exert a disproportionate influence on policy-making (Schneider and Volkert, 1999). Environmental groups, however, may be increasingly effective as counter lobbyists. As Peltzman (1976) has argued, successful politicians never fully respond to a particular interest group, so that regulatory policies reflect a range of competing interests and will be incomplete for each. The costs of achieving a desired goal for any group rises with competing lobby efforts, and the regulatory response may not overlap well with the initial group objective. For these reasons, there can be opportunities for further voluntary negotiations to achieve goals not fully addressed by formal laws, even in light of recognized transaction costs.

Further, the implementation of environmental legislation by regulatory agencies may be affected by bureaucrats' self-interest considerations (Kirchgässner and Schneider, 2003). Environmental agencies can weaken the policies or increase their scope and effectiveness, for instance through the selective choice of monitoring and enforcement levels for specific environmental measures (Oates and Portney, 2003). Regulatory agencies typically have the initial jurisdiction before any legal action may be brought in court. However, in the event of conflicts between several jurisdictional authorities, the courts can play the role of referee to arbitrate cross-sectoral conflicts and oversee that the judgement is executed. Litigation can increase the transaction costs of conflict resolution by polarizing the different parties, inflating the need for information, and generating further delays (Hanna, 2001).

\subsection{Level 3 - governance}

In Williamson's transaction cost approach, governance structures are set up to organize transactions, i.e. transfers of rights between economic agents. Williamson $(1996,1998)$ recognizes four different types of governance form: the market (based on autonomous decision and price signal coordination), the hierarchy (based on subordination links between agents), a variety of hybrid forms (that borrow from market and hierarchies), and public bureaus (to address regulation and redistribution issues). Governments and public bureaus are typically charged with regulation of extractive-use sectors and organize transactions to limit extraction and to deal with allocation issues. However, these governance structures are designed to regulate a single set of users and have a limited ability to organize transactions across sectors or address cross-jurisdictional externalities. In some cases, cross-sectoral entities can be established but might only have an advisory/consultative role without enough leverage to tackle problems. Regarding ecosystem management, hybrid forms of governance may be well suited to cope with complexity while being flexible enough for trust to develop (Muradian and Rival, 2012; Sanchirico et al., 2010; Scemama and Levrel, 2019). 
Designing effective institutions with a cross-sectoral focus requires characterizing and minimizing the transaction costs associated with addressing inter-group conflicts, particularly those that may arise from the imposition of disproportionate costs. Traditional top-down regulations (e.g., 'polluters pay' approaches) typically are not well suited to address dynamic factors such as climate change and shifting political agendas, and are associated with high transaction costs in adjustment (Libecap, 2016). Collaborative governance frameworks, inspired by Ostrom's design principles for collective action (Ostrom 1990), generally prescribe getting all stakeholders together and having them agree on collective rules. However, Ostrom's original arguments for successful collective action emphasized relatively small groups and similar objectives (Cox et al. 2010), conditions that do not correspond to the cross-sector problems examined here. Expanding the groups involved in policy negotiations potentially broadens support for intervention, but introduces additional coordination costs that may reduce the chance of an agreement that fully addresses the externality problem. The group becomes larger with demands that are more heterogeneous. Accordingly, there are tradeoffs with no clear resolution to the dilemma (Lubell et al., 2019).

Distributional issues are one of the key challenges that cross-sectoral governance faces. Stakeholders are likely to oppose to the allocation of the costs and benefits associated with addressing the conflicts if the selected policy measures can leave them worse off. Whether governance is structured to provide means of compensation across sectors appears particularly important. Conflicts over the distribution of benefits and costs can impede institutional change even when expected aggregate gains are large (Cox et al., 2010). Governance structures that provide means of bargaining or arbitration may thus be more likely to generate solutions that address tradeoffs across sectors. Assignment of property rights of some type across sectors or as indicated in the examples above, use of alternative, tradable mechanisms can allow for bargaining that mitigates open-access losses (Coase, 1960).

\subsection{Level 4 - Resource allocation}

The final institutional level in Williamson's framework deals with resource allocation and describes the individual incentives that determine the opportunity cost of resource use and conservation. Perhaps the most important challenge to taking into account cross-sectoral externalities in resource allocation is the difficulty in measuring the magnitude and distribution of externality costs across the different parties, especially when the resource is broadly spread so that different groups/sectors may observe different resource conditions. System complexity in terms of linkages between the different ecosystem services that are involved in the conflicts can make it difficult to clarify what trade-offs are being made when the resources in dispute are allocated. For instance, the transmission of externality through indirect impacts on ecosystem processes that produce ecosystem goods (e.g., trawling impacting nursery habitats) or via interactions among multiple interconnected resources (e.g., reduced stream flow caused by agricultural water diversions affecting wild salmon production) can make externalities more variable and less visible, especially for large-scale resources where the distribution of externality costs can vary (Ayres et al., 2018). Further, there are inherent difficulties in measuring non-use values via revealedpreference (Boyle, 2017) or stated-preference techniques (Johnston et al., 2017) and thus to develop policy proposals that account for those. Compliance is also important to the effectiveness of management measures and it is undermined if the costs and benefits of addressing externalities are not distributed proportionally. Establishing trust across sectors may be more difficult than within sectors, making it particularly challenging to enforce a cross-sectoral agreement. 
The possibility of using side payments to mitigate opposition from parties who expect to be left worse off by new institutional arrangements also appears as one of the major elements that can influence the political feasibility of resolving cross-sectoral conflicts (Ovando et.al, 2021). Boyce (1998) finds that forcing winners to compensate losers ('beneficiary pays' schemes) reduces rent-seeking activities by those who are benefiting from solutions that otherwise would impose more direct costs and fewer benefits on other constituencies and sectors. Side payments such as subsidies or property rights reallocation can provide means of bargaining across sectors.

\section{Coasean bargaining to mitigate cross-sectoral conflicts}

Coase (1960) envisioned a bargaining setting emphasizing the importance of the allocation of property rights and the central role of voluntary bargaining among stakeholder groups, including exchange of property rights and side payments. Coase illustrated his arguments with simple examples but acknowledged that transaction costs could limit what was possible. Libecap (2016) found that the transaction costs of defining property rights and engaging in Coasean bargaining are not necessarily higher than the transaction costs involved in political intervention via traditional regulation and taxes (i.e., the transaction costs associated with the formation of interest groups, lobbying, political competition, and oversight of bureaucracies).

As we have argued, cross-sectoral externalities can be more problematic to address. As negative effects rise, however, a Coasean approach can offer a way forward. Standard regulation typically is single sector/user group focused and small group collective action generally will not fit the case at hand. Coasean bargaining, however, can go across sectors and user groups if there can be a suitable mechanism, even if it is not a formal property right. Coasean bargaining may offer a solution for setting conservation objectives collaboratively and for negotiating over costs and benefits once that objective has been established (Ovando et al., 2021). Existing ranking of resource users or claimants based on historical use can provide a basis for granting of some form of initial property rights. Allowing previous users to exchange in some manner with other sectors (e.g., through easements), perhaps even mandate that they exchange with other sectors, would provide a way of including new claimants without undermining previous users.

Barriers to Coasean solutions in cases of multi-sector conflicts may exist. First, the allocation of rights can have distributional effects and some parties may oppose to the assignment of formal property rights. Such opposition is likely when some groups are left out of the initial allocation or when the assignment of rights among groups is perceived as unfair by some parties. However, assigning rights does allow parties to bargain and adjust compared to traditional regulations that may not (Libecap, 2016). Moreover, as illustrated by the Bigeye tuna and the Fiordland Marine Guardians case examples, the basis of exchange can be instruments that are not formal property rights, allowing for Coasean bargaining at lower transaction costs than would be required for the allocation and trade of formal property rights. Second, there may be differential internal coordination costs within groups - for instance if some groups are more heterogeneous and less cohesive than others - that could affect the outcomes of a Coasean bargain. However, such heterogeneous groups would also face higher costs of forming a cohesive position in lobbying for government intervention or in negotiating with other parties to seek consensus in a deliberative approach. In the end, the constraints of group heterogeneity on Coasean bargaining are not necessarily more severe than forming a uniform effort for government policies or for consensus-based collective action. 
Coasean bargaining arrangements that have been successful at mitigating conflicts between use and biodiversity conservation include conservation easements and land trusts (Parker, 2004), wetland mitigation banking (Levrel et al., 2017), habitat credits (Wallace et al., 2015), water markets (Grafton et al., 2010), and others (Anderson and Libecap, 2014). While these often are partial solutions, or second best, they can be an improvement over the alternative of no or very limited collaboration, opposition, and evasion. In these arrangements, conservation advocates pay to improve biodiversity conservation or resource users pay to obtain additional use rights.

Institutions facilitating Coasean bargaining typically fall within the governance level of Williamson's framework (Level 3 in Table 1 and Figure 1), and are nested into the broader institutional environment including laws and property rights (Level 2). In addition, Coasean bargaining provides individual incentives for stakeholder to negotiate and adjust, which is relevant to the resource allocation level of Williamson's framework (Level 4). Coasean bargaining arrangements can also relate to the social embeddedness level (Level 1) via the increasingly acknowledged idea that resource users must have a "social license to operate", i.e. that they need to be accountable for their broader impact on ecosystems (Gunningham et al., 2004). To illustrate further, we provide examples of Coasean bargaining solutions within the cross-sector externalities described earlier.

In the Western US, voluntary market-based water transactions have been widely used as a way of balancing streamflow needs for imperiled salmon species with historical water uses (Richter et al., 2019). NGOs and state water trusts purchased and leased water rights from private irrigators, restoring flows through thousands of stream kilometers in dewatered salmonid habitats (McCoy et al., 2018). Dam owners and operators are generally required to mitigate their impacts to fish and wildlife and fund various salmon recovery actions such as habitat restoration, wild stock supplementation via conservation hatcheries, and spills and flow operation for fish (NPCC, 2019). In one remarkable instance of dam relicensing, Indian tribes who owned the rights to fish salmon on the Deschutes River were able to enter a settlement agreement with the dam license holder and became majority owners of the largest hydroelectric project within the State of Oregon (Jud, 2006). This diversification of shareholder interests has led to measures that better balance electricity generation and salmon conservation, contributing to significant increases in salmon returns in recent years (Simpson, 2019).

In the realm of sea turtle conservation, performance payment approaches (i.e., direct payments that vary as a function of conservation success) taking place around the world have achieved substantial behavioral changes relating to egg harvest and at-sea takes (Ferraro and Gjertsen, 2009). These initiatives include nesting beach protection programs implemented by NGOs where local individuals receive payments for nest identification and protection that vary according to hatching success. They also include bycatch-release incentive programs whereby a fisher that accidentally catches a turtle in its net can receive a payment that depends on estimated damage to the net in exchange of releasing the turtle alive.

Regarding wolf management, Thiel et al. (2012) describe a compensation scheme established in Saxony (Germany) that has substantially improved the welfare of livestock owner while avoiding illegal killing of wolves. Regional authorities worked with environmental NGOs to implement ex-post financial compensation for damaged livestock to increase acceptance of wolf protection. Compensation was contingent upon undertaking protecting measures (herd protection dogs and appropriate fences) to overcome moral hazard issues. 
Each of these cross-sectoral arrangements is described within Williamson's framework in Table 1. This categorization identifies the institutional factors that must be considered in achieving collaboration as well as the opportunities for securing it when each level is considered.

Table 1: Examples of institutional considerations in case examples in relation to the four levels of Williamson's framework

\begin{tabular}{|l|l|l|l|}
\hline Level of institutions & $\begin{array}{l}\text { Salmon conservation on the } \\
\text { US West Coast }\end{array}$ & $\begin{array}{l}\text { Pacific Leatherback Sea } \\
\text { turtle conservation }\end{array}$ & $\begin{array}{l}\text { Wolf management in } \\
\text { Europe }\end{array}$ \\
\hline $\begin{array}{l}\text { Level 1 - Social } \\
\text { Embeddedness }\end{array}$ & $\begin{array}{l}\text { Important cultural value of } \\
\text { salmon, relevance of animal } \\
\text { cruelty concerns in predator } \\
\text { control issues }\end{array}$ & $\begin{array}{l}\text { Importance of traditions and } \\
\text { beliefs associated with turtle } \\
\text { egg consumption }\end{array}$ & $\begin{array}{l}\text { Increasing consideration of } \\
\text { the existence value of } \\
\text { wolves }\end{array}$ \\
\hline $\begin{array}{l}\text { Level 2- Institutional } \\
\text { Environment }\end{array}$ & $\begin{array}{l}\text { Protection under the ESA, } \\
\text { balance of energy needs with } \\
\text { conservation under the } \\
\text { Northwest Power Act, Indian } \\
\text { treaties, water rights }\end{array}$ & $\begin{array}{l}\text { Treaty obligations of states } \\
\text { under the UNCLOS \& the } \\
\text { CBD, Protection under } \\
\text { CITES }\end{array}$ & $\begin{array}{l}\text { Protection under the Bern } \\
\text { convention and the Habitats } \\
\text { Directive }\end{array}$ \\
\hline Level 3-Governance & $\begin{array}{l}\text { Development of water markets } \\
\text { Development of } \\
\text { performance payment } \\
\text { approaches }\end{array}$ & $\begin{array}{l}\text { Implementation of ex-post } \\
\text { financial compensation } \\
\text { scheme }\end{array}$ \\
\hline $\begin{array}{l}\text { Level } 4-\text { Resource } \\
\text { allocation }\end{array}$ & $\begin{array}{l}\text { NGOs and State trusts leasing } \\
\text { water rights }\end{array}$ & $\begin{array}{l}\text { Involvement of local } \\
\text { communities in } \\
\text { conservation programs }\end{array}$ & $\begin{array}{l}\text { Adjustment of farmers to } \\
\text { the new incentive } \\
\text { framework }\end{array}$ \\
\hline
\end{tabular}

\section{Conclusion}

We undertook an institutional analysis of how the existence of governance conflicts at the interface of multiple sectors and jurisdictions undermines attainment of conservation objectives. The multiplicity of ecosystem services involved in the conflicts increases system complexity and thereby the likelihood multi-jurisdictional conflicts. In addition, contrasted values for use and non-use sectors make it difficult to assign property rights and constrain the scope of tradeoff possibilities. Examining sources of transaction costs facilitates consideration of practical issues that are often ignored in institutional design (McCann, 2013). For example, transaction costs can be lowered by supporting research programs to reduce uncertainties about the distribution of externality costs, arranging longterm means of side payments across sectors to reconcile diverging preferences, organizing transparent methods for collecting information and interpreting data to reduce information asymmetry, or establishing credible and effective enforcement regimes (Libecap, 2014).

An examination of impediments to more integrated institutional regimes highlighted the relevance and interconnectedness of the different levels of institutions used by Williamson (2000) to analyze institutional change. Notably, opportunities for institutional change may arise from a rapid shift in norms and values related to the realization that human activities are driving climate change in Anthropocene, speeding up the timescale of institutional change in the higher levels (social embeddedness, institutional environment, and governance) of the Williamson framework. For example, the Marine Mammal Protection Act was recently amended to allow for the lethal removal of pinnipeds in the Columbia River and its tributaries to protect endangered and threatened populations of salmon (United States. Cong., 2018). Similar motivations may also create impetus to amend the Endangered Species Act to allow consideration of trade-offs between objectives or cost concerns to promote cross-sectoral solutions. Moreover, new social media available to people to share information can make change happen more quickly. Campaigns on social 
media can increase political pressure on decision makers and precipitate governance shift or overturn policy intervention within a few days.

An improved understanding of the sources and magnitude of transaction costs can help to identify opportunities for feasible arrangements that promote cooperation between sectors or integration of management across sectors. Ultimately, reaching agreement on a policy choice to mitigate cross-sectoral externalities requires attention to the specificities of the stakeholders, resources, and institutions involved in the conflicts as identified in Williamson's framework. When considering practical approaches to addressing crosssectoral conflicts, it is useful to recognize that marine ecosystems cannot be returned to historical pristine conditions. All solutions will be second-best because of the trade-offs imposed by competing parties. Cross-sectoral coordination for conservation requires longterm stakeholder and political commitments. Accordingly, Pareto-improving arrangements are likely to be more durable. Voluntary agreements within a framework envisioned by Coase (1960) may be the most fruitful way to proceed. They can build upon incentivebased fishery sector systems (Grafton et al., 2006) and would require extension of property rights to include impacts on ecosystem resources as illustrated by Wallace et al. (2015) and Holland (2018). Coasean solutions allow sectors to bargain and adjust to address the externality problem and can offer opportunities to move on from stalemate.

\section{References}

Aidt, T.S. (1998). Political internalization of economic externalities and environmental policy. Journal of Public Economics, 69(1), 1-16.

Anderson, T.L., Libecap, G.D. (2014). Environmental Markets: A Property Rights Approach. New York: Cambridge University Press.

Arrow, K.J. (1974). The limits of organization. WW Norton \& Company.

Ayres, A.B, Edwards, E.C., Libecap, G.D. (2018). How transaction costs obstruct collective action: The case of California's groundwater. Journal of Environmental Economics and Management. 91 46-65.

Batie, S.S. (2008). Wicked problems and applied economics. American Journal of Agricultural Economics 90 (5), 1176-1191.

Bellanger, M., Speir, C., Blanchard, F., Brooks, K., Butler, J. R., Crosson, S., ... \& Young, J. C. (2020). Addressing marine and coastal governance conflicts at the interface of multiple sectors and jurisdictions. Frontiers in Marine Science, 7:544440.

Bishop, R.C. (1978). Endangered species and uncertainty: the economics of a safe minimum standard. American journal of agricultural economics 60.1:10-18.

Boyce, J.R. (1998). Rent-seeking in natural resource quota allocations. Public Choice, 96(3-4), 271-294.

Boyle, K.J. (2017). Introduction to revealed preference methods. In A primer on nonmarket valuation (Second edition). Springer, Dordrecht.

Bromley, D.W. (1992). The commons, common property, and environmental policy. Environmental and resource economics 2.1: 1-17.

Bryson, J.M., Crosby, B.C., Stone, M.M. (2006). The design and implementation of CrossSector collaborations: Propositions from the literature. Public administration review, $66,44-55$.

Burns, S. (2008). Environmental policy and politics: trends in public debate. Natural Resources \& Environment, 23(2), 8-12. 
Coase, R.H. (1960). The Problem of Social Cost. The journal of law and economics 3: 144.

Coggan, A., Whitten, S.M., Bennett, J. (2010). Influences of transaction costs in environmental policy. Ecological economics, 69(9), 1777-1784.g

Cox, M., Arnold, G., Villamayor Tomás, S. (2010). A review of design principles for community-based natural resource management. Ecology and Society 15(4): 38.

Crowder, L.B., Osherenko, G., Young, O.R., Airamé, S., Norse, E.A., Baron, N., ..., Wilson, J.A. (2006). Resolving Mismatches in U.S. Ocean Governance. Science 313:617-618.

Dahlman, C.J. (1979). The problem of externality. The journal of law and economics 22(1):141-162.

Demsetz, H. (1967). Toward a theory of property rights. American Economic Review 57(2):347-59.

Dirzo, R., Young, H.S., Galetti, M., Ceballos, G., Isaac, N.J., Collen, B. (2014). Defaunation in the Anthropocene. Science, 345(6195), 401-406.

Eggertsson, T. (1990). Economic Behavior and Institutions. Cambridge: Cambridge University Press.

Ferraro, P.J., Gjertsen, H. (2009). A global review of incentive payments for sea turtle conservation. Chelonian Conservation and Biology, 8(1), 48-56.

Folke, C., Carpenter, S., Walker, B., Scheffer, M., Elmqvist, T., Gunderson, L., Holling, C.S. (2004). Regime shifts, resilience, and biodiversity in ecosystem management. Annu. Rev. Ecol. Evol. Syst., 35, 557-581.

Folke, C., Pritchard Jr, L., Berkes, F., Colding, J., Svedin, U. (2007). The problem of fit between ecosystems and institutions: ten years later. Ecology and society, 12(1).

Fung, A., Wright, E.O. (2001). Deepening democracy: Innovations in empowered participatory governance. Politics \& Society, 29(1), 5-41.

Gehring, T.M., Potter, B.A. (2005). Wolf habitat analysis in Michigan: an example of the need for proactive land management for carnivore species. Wildlife Society Bulletin, 33(4), 1237-1244.

Gjertsen, H., Squires, D., Dutton, P.H., Eguchi, T. (2014). Cost-effectiveness of alternative conservation strategies with application to the Pacific leatherback turtle. Conservation Biology, 28(1), 140-149.

Gordon, H.S. (1954). The economic theory of a common-property resource: the fishery. In Classic Papers in Natural Resource Economics (pp. 178-203). Palgrave Macmillan, London.

Grafton, R.Q., Arnason, R., Bjørndal, T., Campbell, D., Campbell, H.F., Clark, C.W., ... \& Kirkley, J.E. (2006). Incentive-based approaches to sustainable fisheries. Canadian Journal of Fisheries and Aquatic Sciences, 63(3), 699-710.

Grafton, R.Q., Landry, C., Libecap, G.D., O'Brien, R.J. (2010). Water markets: Australia's Murray-Darling basin and the US Southwest. National Bureau of Economic Research, Working Paper 15797. Cambridge, MA, USA.

Grant, Z.P., Tilley, J. (2019). Fertile soil: explaining variation in the success of Green parties. West European Politics, 42(3), 495-516.

Grip, K. (2017). International marine environmental governance: A review. Ambio, 46(4), 413-427.

Groeneveld, R. A. (2020). Welfare economics and wicked problems in coastal and marine governance. Marine Policy, 117, 103945. 
Guardians of Fiordland's Fisheries and Marine Environment Inc. (2003). Fiordland Marine Conservation Strategy. Wellington, New Zealand.

Guardians of Fiordland's Fisheries and Marine Environment Inc. (2020). Annual Report 2019/20. Wellington, New Zealand.

Gunningham, N., Kagan, R. A., Thornton, D. (2004). Social license and environmental protection: why businesses go beyond compliance. Law \& Social Inquiry, 29(2), 307341.

Hahn, R.W. (1990). The political economy of environmental regulation: Towards a unifying framework. Public Choice, 65(1), 21-47.

Hanna, S. (2001). More than meets the eye: the transaction costs of litigation. Ocean \& Coastal Law Journal, 7(1), 13-19.

Hardin, G. (1968). The tragedy of the commons. Science 162.3859: 1243-1248.

Hatcher, A., Jaffry, S., Thébaud, O., Bennett, E. (2000). Normative and social influences affecting compliance with fishery regulations. Land Economics, 448-461.

Hiedanpää, J., Bromley, D.W. (2016). Environmental heresies: The quest for reasonable. Springer.

Hobbs, Richard J., Higgs, E.S., Hall, C. (2013). Novel ecosystems: intervening in the new ecological world order. John Wiley \& Sons.

Holland, D.S. 2018. Collective Rights-Based Fishery Management A Path to EcosystemBased Fishery Management. Annual Review of Resource Economics 10:469-85.

IPBES (2019). Summary for policymakers of the global assessment report on biodiversity and ecosystem services of the Intergovernmental Science-Policy Platform on Biodiversity and Ecosystem Services. Intergovernmental Platform on Biodiversity and Ecosystem Services, Bonn, Germany.

Johnston, R.J., Boyle, K.J., Adamowicz, W., Bennett, J., Brouwer, R., Cameron, T.A., ..., Vossler, C.A. (2017). Contemporary guidance for stated preference studies. Journal of the Association of Environmental and Resource Economists, 4(2), 319-405

Jud, S.B. (2006). Salmon as Lazarus in the Oregon Desert: The Historic Settlement and Relicensing of the Pelton-Round Butte Project. Natural Resources Journal, 46(4), 10431079.

Kalt, J.P., Zupan, M.A. (1984). Capture and ideology in the economic theory of politics. The American Economic Review, 74(3), 279-300.

Kirchgässner, G., Schneider, F. (2003). On the political economy of environmental policy. Public Choice, 115(3-4), 369-396.

Krutilla, K., Krause, R. (2011). Transaction costs and environmental policy: An assessment framework and literature review. International Review of Environmental and Resource Economics, 4(3-4), 261-354.

Lackey, R.T. (2017). Science and salmon recovery. pp. 69-94. In: New Strategies For Wicked Problems: Science and Solutions in the 21st Century, Edward P. Weber, Denise H. Lach, and Brent S. Steel, editors, Oregon State Press, Corvallis, Oregon, 223 pp.

Levrel, H., Scemama, P., Vaissière, A.C. (2017). Should we be wary of mitigation banking? Evidence regarding the risks associated with this wetland offset arrangement in Florida. Ecological Economics, 135, 136-149.

Libecap, G.D. (1989). Distributional issues in contracting for property rights. Journal of Institutional and Theoretical Economics: 6-24.

Libecap, G.D. (1994). The Conditions for Successful Collective Action. Journal of Theoretical Politics 6, 563-592. 
Libecap, G.D. (2005). State regulation of open-access, common-pool resources. In Handbook of new institutional economics (pp. 545-572). Springer, Boston, MA.

Libecap, G.D. (2014). Addressing global environmental externalities: Transaction costs considerations. Journal of Economic Literature, 52(2), 424-479.

Libecap, G.D. (2016). Coasean bargaining to address environmental externalities. National Bureau of Economic Research, Working Paper 21903. Cambridge, MA, USA.

Lubell, M., Mewhirter, J., Berardo, R., Scholz, J. (2019). The Origins of Conflict in Polycentric Governance Systems. Prepared for delivery at the Workshop on the Ostrom Workshop (WOW6) conference, Indiana University Bloomington.

Lute, M.L., Attari, S.Z. (2017). Public preferences for species conservation: choosing between lethal control, habitat protection and no action. Environmental Conservation, 44(2), 139-147.

Marshall, G.R. (2013). Transaction costs, collective action and adaptation in managing complex social-ecological systems. Ecological Economics, 88, 185-194.

McCann, L. (2013). Transaction costs and environmental policy design. Ecological Economics, 88, 253-262.

McCann, L., Colby, B., Easter, K.W., Kasterine, A., \& Kuperan, K.V. (2005). Transaction cost measurement for evaluating environmental policies. Ecological economics, 52(4), 527-542.

McCoy, A.L., Holmes, S.R., Boisjolie, B.A. (2018). Flow restoration in the Columbia River Basin: an evaluation of a flow restoration accounting framework. Environmental management, 61(3), 506-519.

Mettepenningen, E., van Huylenbroeck, G. (2009). Factors influencing private transaction costs related to Agri-environmental Schemes in Europe. In: Bruwer, F., van der Heide, M. (Eds.), Multifunctional Rural Land Management: Economics and Policies. London: Earthscan.

Millennium Ecosystem Assessment (MEA) (2005). Ecosystems and Human Well-being: Synthesis. Island Press, Washington, DC.

Morrison, M., Durante, J., Greig, J., Ward, J. (2008). Encouraging participation in market based instruments and incentive programs. Final report prepared for Land and Water Australia.

Muradian, R., Rival, L. (2012). Between markets and hierarchies: the challenge of governing ecosystem services. Ecosystem Services 1, 93-100.

Neely, C., Bourne, M., Chesterman, S., Kouplevatskaya-Buttoud, I., Bojic, D., Vallée, D. (2017). Implementing Agenda 2030 in Food and Agriculture: accelerating policy impact through cross-sectoral coordination at the country level. FAO, Rome.

Northwest Fisheries Science Center. (2015). Status review update for Pacific salmon and steelhead listed under the Endangered Species Act: Pacific Northwest.

NPCC. (2019). 2018 Columbia River Basin Fish and Wildlife Program Costs Report. 16th Annual Report to the Northwest Governors. March 2019, Portland, OR.

Oates, W.E., Portney, P.R. (2003). The political economy of environmental policy. In Handbook of environmental economics (Vol. 1, pp. 325-354). Elsevier.

Ostrom, E. (1990). Governing the commons. Cambridge university press.

Ostrom, E. (2009). A general framework for analyzing sustainability of social-ecological systems. Science, 325(5939), 419-422. 
Ovando, D., Libecap, G.D., Millage, K.D., Thomas, L. (2021). Coasean Approaches to Ending Overfishing: Bigeye Tuna Conservation in the Western and Central Pacific Ocean. Marine Resource Economics, 36 (1)

Parker, D.P. (2004). Land trusts and the choice to conserve land with full ownership or conservation easements. Natural Resources Journal, 44(2), 483-518.

Pashigian, B.P. (1985). Environmental Regulation: Whose Self-Interests Are Being Protected?. Economic Inquiry, 23(4), 551-584.

Peltzman, S. (1976) Toward a More General Theory of Regulation. Journal of Law \& Economics 19(2): 211-240

Pigou, A.C. (1932). The Economics of Welfare. 4th ed. London: Macmillian and Co.

Rice, J.C. (2011). Achieving coherent policies for conservation and sustainable use of marine ecosystems. Conservation Biology, 25(6), 1065-1068.

Richter, B.D., Andrews, S., Dahlinghaus, R., Freckmann, G., Ganis, S., Green, J., ..., Shalvey, J. (2019). Buy Me a River: Purchasing Water Rights to Restore River Flows in the Western USA. Journal of the American Water Resources Association 56(1), 1-15.

Salvatori, V., Linnell, J. (2005). Report on the Conservation Status and Threats for Wolf (Canis lupus) in Europe. PVS/Inf (2005) 16. Council of Europe, Strasbourg.

Sanchirico, J.N., Eagle, J., Palumbi, S., Thompson, B.H. (2010). Comprehensive planning, dominant-use zones, and user rights: a new era in ocean governance. Bulletin of Marine Science, 86(2), 273-285.

Scarlett, L., Boyd, J. (2015). Ecosystem services and resource management: institutional issues, challenges, and opportunities in the public sector. Ecological Economics, 115, 310.

Scemama, P., Levrel, H. (2019). Influence of the Organization of Actors in the Ecological Outcomes of Investment in Restoration of Biodiversity. Ecological Economics, 157, 7179.

Schneider, F., Volkert, J. (1999). No chance for incentive-oriented environmental policies in representative democracies? A Public Choice analysis. Ecological Economics, 31(1), 123-138.

Scott, A. (1955). The fishery: the objectives of sole ownership. Journal of political Economy $63.2: 116-124$.

Simpson, R. D. (2019). Saving Salmon and Saving Money. How far upstream can property rights extend?. PERC Reports, 38(2), 35-39.

Spotila, J.R., Reina, R.D., Steyermark, A.C., Plotkin, P.T., Paladino, F.V. (2000). Pacific leatherback turtles face extinction. Nature, 405(6786), 529.

Tapilatu, R.F., Dutton, P.H., Tiwari, M., Wibbels, T., Ferdinandus, H.V., Iwanggin, W.G., Nugroho, B.H. (2013). Long-term decline of the western Pacific leatherback, Dermochelys coriacea: a globally important sea turtle population. Ecosphere, 4(2), 115.

Thiel, A., Schleyer, C., Plieninger, T. (2012). Wolves are mobile, while fruit trees are not! How characteristics of resources and supranational regulatory frameworks shape the provision of biodiversity and ecosystem services in Germany. Environmental Policy and Governance, 22(3), 189-204.

Tomillo, P.S., Saba, V.S., Piedra, R., Paladino, F.V., Spotila, J. R. (2008). Effects of illegal harvest of eggs on the population decline of leatherback turtles in Las Baulas Marine National Park, Costa Rica. Conservation biology, 22(5), 1216-1224. 
United States. Cong. (2018). Endangered Salmon Predation Prevention Act. Public Law 115-329, 115th Cong., S 3119. Washington: GPO.

Volden, C., Wiseman, A.E. (2007). Bargaining in legislatures over particularistic and collective goods. American Political science review, 101(1), 79-92.

Wallace, S., Turris, B., Driscoll, J., Bodtker, K., Mose, B., Munro, G. (2015). Canada's Pacific groundfish trawl habitat agreement: A global first in an ecosystem approach to bottom trawl impacts. Marine Policy, 60, 240-248.

Williamson, O.E. (1996). The mechanisms of governance. Oxford University Press.

Williamson, O.E. (1998). Transaction cost economics: how it works; where it is headed. De economist, 146(1), 23-58.

Williamson, O.E. (2000). The new institutional economics: taking stock, looking ahead. Journal of economic literature, 38(3), 595-613.

Yandle, B. (1989). The Political Limits of Environmental Regulation: Tracking the Unicorn. New York, Quorum Books.

Young, O.R. (2010). Institutional dynamics: Resilience, vulnerability and adaptation in environmental and resource regimes. Global Environmental Change, 20(3), 378-385. 